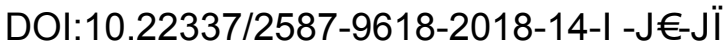

\title{
ONE FEATURE OF THE CONSTRUCTIVE SOLUTIONS OF THE LATTICE GIRDER
}

\author{
Mikhail N. Kirsanov \\ National research University "MPEI”, Moscow, RUSSIA
}

\begin{abstract}
The problem of the deflection of a planar symmetric statically determinable truss with a double lattice depending on the number of panels was solved in an analytical form. The angle of inclination of the ascending and descending rods of the truss is different. A load is applied to the truss, evenly distributed over the nodes of the lower chord. Special operators of the Maple computer math system and the induction method were used to generalize individual particular solutions to an arbitrary case. Formulas are obtained for the forces the most compressed and stretched truss rods. Cases of kinematic variability of the structure are revealed. A picture of the possible speeds of truss nodes in these cases is constructed. The asymptotic behavior of the deflection is found with a large number of panels and a fixed span length. The deflection was determined by the formula of Maxwell - Mohr.
\end{abstract}

Keywords: truss, deflection, induction, Mohr' integral, Maple

\section{ОСОБЕННОСТЬ ОДНОГО КОНСТРУКТИВНОГО РЕШЕНИЯ РЕШЕТКИ БАЛОЧНОЙ ФЕРМЫ}

\author{
М.Н. Кирсанов \\ Национальный исследовательский университет «МЭИ», г. Москва, РОССИЯ
}

\begin{abstract}
Аннотация: В аналитической форме решена задача о прогибе плоской симметричной статически определимой фермы с двойной решеткой в зависимости от числа панелей. Угол наклона восходящих и нисходящих раскосов фермы разный. К ферме приложена нагрузка, равномерно распределенная по узлам нижнего пояса. Использованы специальные операторы системы компьютерной математики Марle и метод индукции для обобщения отдельных частных решений на произвольный случай. Получены формулы для усилий в наиболее сжатых и растянутых стержнях фермы. Выявлены случаи кинематической изменяемости конструкции. Построена картина возможных скоростей узлов фермы в этих случаях. Найдена асимптотика прогиба при большом числе панелей и фиксированной длине пролета. Прогиб определялся по формуле Максвелла - Мора.
\end{abstract}

Ключевые слова: ферма, прогиб, индукция, формула Максвелла - Mopa, Maple

\section{FORMULATION OF THE PROBLEM}

The calculation of building structures is traditionally carried out by numerical methods, based mainly on the finite element method, incorporated in most standard computational packages. Along with this, recently the analytical line of research has become widespread. In particular, for planar [1-8] and spatial [9-11] statically definable trusses with the property of regularity, exact solutions were obtained for the deflection problem under the action of various loads. The main feature of these solutions is the inclusion of a number of panels in the truss parameters. This became possible with the advent of methods of symbolic mathematics (Reduce, Maple, Mathematica, Maxima, Derive, and others), allowing not only to solve problems of forces in the bars of a structure in symbolic form, but also to find generalizations of these solutions to an arbitrary number of rods or cells in truss. The latter can be done by induction, for the implementation of which (the compilation and solution of recurrent equations) in modern systems of computer mathematics there are corresponding special 
operators. It should be noted that together with the solution of the main problem — the derivation of a compact formula for the expression of the deflection, using the methods of computer mathematics, it became possible to find the features of the structures of some complex rod structures that manifest themselves in their kinematic degeneration. It is these problems that are solved in the present work as applied to a planar beam truss with a diagonal double lattice.

A review of some analytical solutions for planar trusses is contained in [12].

\section{TRUSS MODEL, CALCULATION OF FORCES}

In a girder truss with parallel belts, the descending and ascending braces have a different slope. In the middle of the truss there is a shortened stand with a V-shaped fastening to the upper belt (Fig. 1). In this design, it is difficult to unambiguously single out a separate panel, so we will conditionally assume that the panel is defined only by the rods of the lower and upper belts and has a length of $a$. The number of panels in the truss is $2 n$, which corresponds to $m=8 n+10$ rods together with three supporting ones. Since the number of hinges, the equilibrium of which is considered when determining the forces in the rods is equal here is $m_{s}=4 n+8$, the truss is statically definable.

As with most trusses with double grids, the usual calculation methods for this truss, such as the cross-section method or the method of successive cutting of knots, are not applicable. In [1-3], a program for computing symbolic forces from the solution of the system of equilibrium equations of all nodes is described. A program written in the language of symbolic mathematics Maple implies the assignment of coordinates of nodes and the order of connecting rods, in the same way as a graph is defined in discrete mathematics. The truss rods and nodes are numbered (Fig. 2), the origin of coordinates is chosen and the coordinates of the hinges are entered:

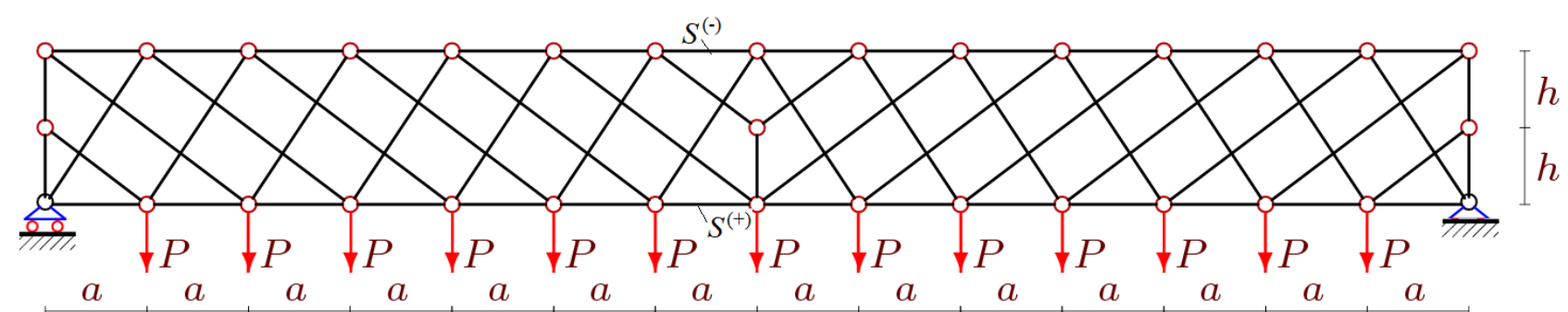

Figure 1. Truss, $n=7$.

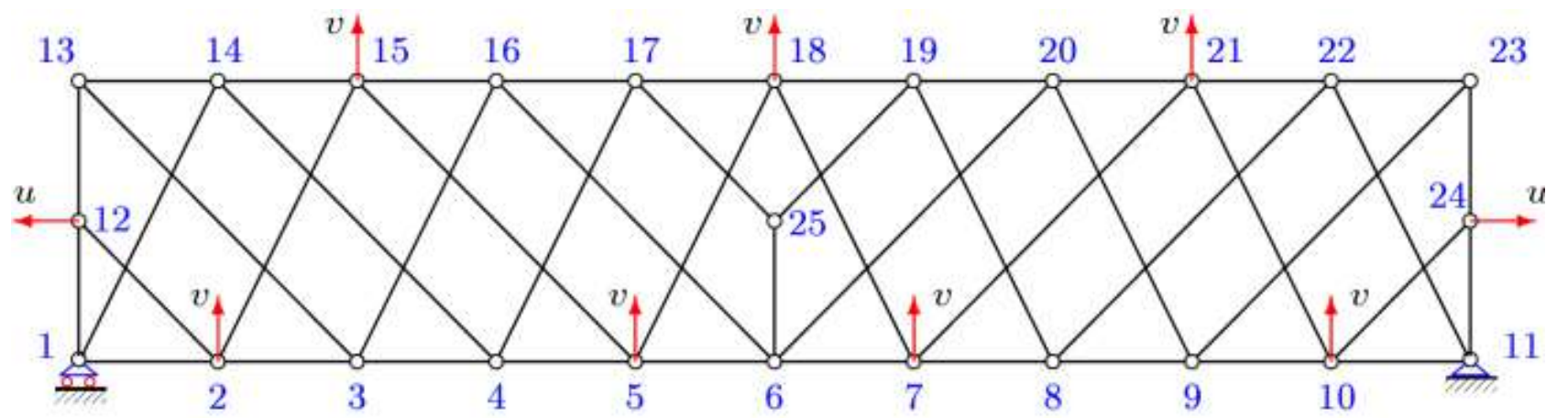

Figure 2. Numbers of rods and nodes, $n=5$. 


$$
\begin{aligned}
& x_{i}=x_{i+2 n+2}=a(i-1), y_{i}=0, \\
& y_{i+2 n+2}=2 h, i=1, \ldots, 2 n+1, \\
& x_{2 n+2}=0, y_{2 n+2}=y_{4 n+4}=h, x_{4 n+4}=2 n a .
\end{aligned}
$$

The order of connecting rods and nodes is given by vectors $\bar{V}$, the coordinates of which correspond to the numbers of finite hinges of the rod. Rods of the lower belt, for example, have the following coordinates:

$$
\left.\bar{V}_{i}=[i, i+1)\right], i=1, \ldots, 2 n .
$$

Similarly, in the cycles, the remaining rods are also set, including the supporting ones:

$$
\begin{aligned}
& \bar{V}_{m-2}=\left[1, m_{s}-2\right], \\
& \bar{V}_{m-1}=\left[2 n+1, m_{s}-1\right], \\
& \bar{V}_{m}=\left[2 n+1, m_{s}\right] .
\end{aligned}
$$

The matrix of the system of equations consists of the direction cosines of the forces, which are calculated by the formulas

$$
\begin{aligned}
& l_{i}=\sqrt{{l_{1, i}{ }^{2}+l_{2, i}{ }^{2}}^{2}}, l_{1, i}=x_{V_{2, i}}-x_{V_{1, i}}, \\
& l_{2, i}=y_{V_{2, i}}-y_{V_{1, i}}, \quad i=1, \ldots, m .
\end{aligned}
$$

In number $V_{j, i}$, the first index $\mathrm{j}$ takes values 1 or 2 and corresponds to the number of the vector $\bar{V}_{i}$ components, the second index corresponds to the number of the rod. Thus, taking into account, each force enters the equilibrium equations of two nodes at the ends of the rod and the projections have different signs, the matrix of direction cosines has the following elements:

$$
\begin{gathered}
G_{t, i}=-l_{j, i} / l_{i}, \quad t=2 V_{i, 2}-2+j, t \leq m, j=1,2, \\
G_{t, i}=l_{j, i} / l_{i}, t=2 V_{i, 1}-2+j, t \leq m, \quad j=1,2, \\
i=1, \ldots, m .
\end{gathered}
$$

The system of equilibrium equations of knots has the form

$$
\mathbf{G} \bar{S}=\bar{B},
$$

where $\bar{S}=\left\{S_{1}, \ldots, S_{m}\right\}$ is a vector of efforts, $\bar{B}$ — is a vector of external loads.

\section{CASE OF KINEMATIC DEGENERATION}

The very first calculations of the forces in symbolic form showed that for $n=2,3,5,6,8$, 9 ... the determinant of the system of equilibrium equations vanishes. It is known that this corresponds to the case of instantaneous variability of the structure. Unfortunately, the known variability criteria do not apply here. There are no two disks connected by parallel rods or rods on the intersecting straight lines. There is no closed polygon of the rods of the lattice, considered by I.M. Rabinovich [13] on the basis of the work of Muller - Breslau [14]. However, for a truss you can find a kinematically consistent picture of the distribution of possible node speeds (Fig. 2), confirming that, indeed, with such a number of panels, the truss turns into a mechanism. Obviously, part of the rods, for example 2-12, 1$2,1-12$, make rotational movements, and part of them is translational: $2-15,5-15,5-18$ and so do symmetrical rods. Most of the nodes 1, 3, 4, 6, $8,9,11 \ldots$ including the supporting ones, remain motionless. The velocities satisfy the obvious relation

$$
u / h=v / a .
$$

In order to exclude unacceptable values of $n$ in a sequential calculation of trusses with different numbers of panels, we introduce the function $n=3 k-2$. Changing in the process of counting the number $k=1,2, \ldots$, we find by the method of induction the regularity of the formation of coefficients in the desired formula for deflection. 


\section{DEFLECTION}

To determine the deflection of the truss, we use the Maxwell - Mohr formula,

$$
\Delta=P \sum_{i=1}^{m-3} S_{i}^{(P)} S_{i}^{(1)} l_{i} /\left(E F_{i}\right)
$$

where the summation is carried out only on the deformable rods of the truss and indicated: $S_{i}^{(1)}$

- forces from a single force applied to the middle of the lower belt (node $n+1$, Fig. 2 ), $S_{i}^{(P)}$

- forces in the rods from a given load, $l_{i}$ lengths of the rods. The stiffness of the rods $E F_{i}$ in the General case are different. Let the area of the sections of the upper and lower zones are expressed in terms of a conditional area:

$$
F_{i}=F / \gamma_{1}, i=1, \ldots, 2 n, i=2 n+3, \ldots, 4 n+3 .
$$

The cross-sectional area of all bars of the grid, including the side racks, have the form:

$$
F_{i}=F / \gamma_{2}, i=2 n+1,2 n+2, i=4 n+4, \ldots, m-3 .
$$

A consistent analytical calculation of trusses with an increasing number of panels revealed that the formula for the deflection is the same:

$$
\Delta=P \frac{C_{1, k} a^{3} \gamma_{1}+\left(C_{2, k} c^{3}+C_{3, k} h^{3}+C_{4, k} d^{3}\right) \gamma_{2}}{8 h^{2} E F}
$$

differing only by coefficients in degrees (cubes) of sizes

$$
a, h, c=\sqrt{a^{2}+h^{2}} \text { and } d=\sqrt{a^{2}+4 h^{2}} \text {. }
$$

In order to find the common term of the sequence of coefficients 4, 257, 2130, 8593, 24236, 55269, 109522, 196445, 327108, 514201 at $a^{3}$, you need to use the special operator rgf_findrecur to find the recurrence equation that this sequence satisfies:

$$
C_{1, k}=5 C_{1, k-1}-10 C_{1, k-2}+10 C_{1, k-3}-5 C_{1, k-4}+C_{1, k-5} \text {, }
$$

and then solve it using the rsolve operator. The solution is

$C_{1, k}=\left(135 k^{4}-360 k^{3}+405 k^{2}-214 k+42\right) / 2$.

Similarly, we obtain expressions for other coefficients:

$$
\begin{aligned}
& C_{2, k}=4\left(6 k^{2}-6 k+1\right), \\
& C_{3, k}=16(3 k-2), \\
& C_{4, k}=3(k-1)^{2} .
\end{aligned}
$$

\section{ANALYSIS OF DEFLECTION}

Consider the case of a truss with a given span $L$ and an arbitrary number of panels, so that

$$
a=L /(2 n) .
$$

The analytical form of the solution allows to clearly identify some of its features. We also fix the total load on the truss

$$
P_{\text {sum }}=(2 n-1) P \text {. }
$$

We introduce notation for the dimensionless deflection of the

$$
\Delta^{\prime}=\Delta E F /\left(P_{\text {sum }} L\right) .
$$

In Figure 3, for $\gamma_{1}=\gamma_{2}=1$ and $\mathrm{L}=100 \mathrm{~m}$, curves of deflection (1) dependence on the number of panels are given, showing that in this formulation the relative deflection does not change with the increase in the number of panels. 


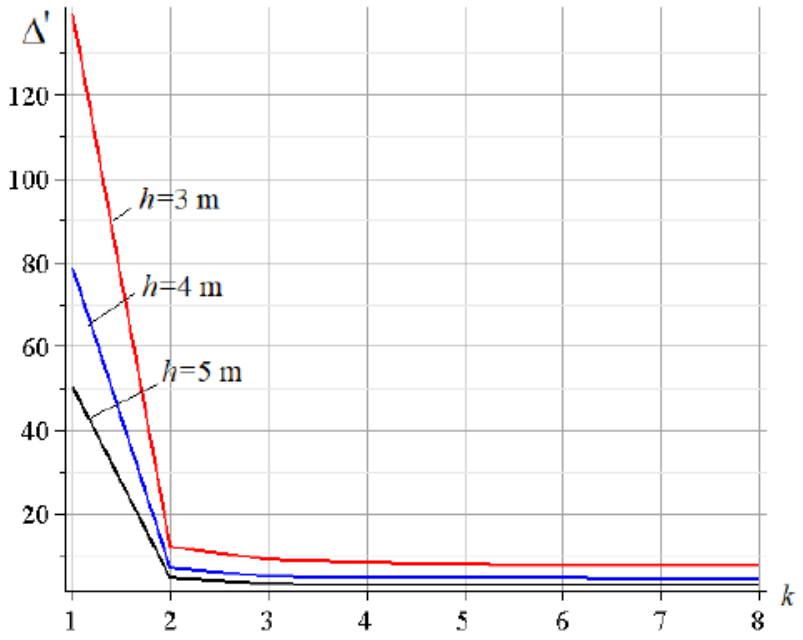

Figure 3. Dependence of deflection on the number of panels.

There is a mild oblique asymptote of the curve. For their analytical expression

$$
\Delta^{\prime}=\Delta_{0}+\mu k
$$

we calculate the limits:

$\mu=\lim _{k \rightarrow \infty} \Delta^{\prime} / k=\gamma_{2} h / L$,

$\Delta_{0}=\lim _{n \rightarrow \infty}\left(\Delta^{\prime}-\mu k\right)=\left(5 \gamma_{1} L^{3}+256 \gamma_{2} h^{3}\right) /\left(768 L h^{2}\right)$.

Similar limits are obtained for truss in [15]. It is interesting to note that the angle of inclination of the asymptote depends only on the rigidity of the lattice $\gamma_{2}$, the height of $h$ and the length of the length of the graph of the deflection decreases, and the angle of inclination of the asymptote is positive. It follows that the curves have weakly expressed extremum points, which can be used to optimize the stiffness of the structure. The dependence of the deflection on the height of the truss (Fig.4) also detects extremum. The curves are constructed under the same assumptions as the graph 3 at $L=50 \mathrm{~m}$.

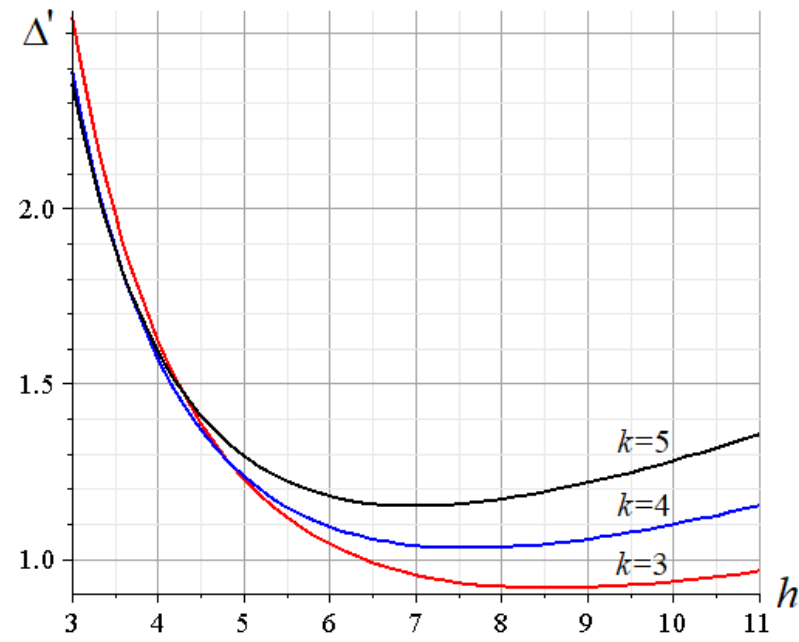

Figure 4. The dependence of the deflection on the height of the truss.

\section{THE FORCES IN THE RODS}

In the process of inductive derivation of the formula for deflection in the program the forces in the rods were also obtained. Maple graphical tools allow to give a visual representation of the distribution of forces in the rods of the belts and the grid. In figure 5, the thickness of the rod lines are proportional to the forces in them. Blue highlighted in rods subjected to compression, red - stretchable. The forces related to the magnitude of the load are also indicated.

As one would expect, with such a load, the most compressed rods are in the middle of the upper belt, the stretched ones are in the middle of the lower one.

For these forces (Fig. 1), the induction method from the analysis of six solutions for trusses with a successively increasing number $k$ associated with the number of panels obtained formulas:

$$
\begin{aligned}
& S^{(-)}=-P a\left(9 k^{2}-10 k+3\right) /(4 h), \\
& S^{(+)}=P a\left(9 k^{2}-10 k+1\right) /(4 h) .
\end{aligned}
$$




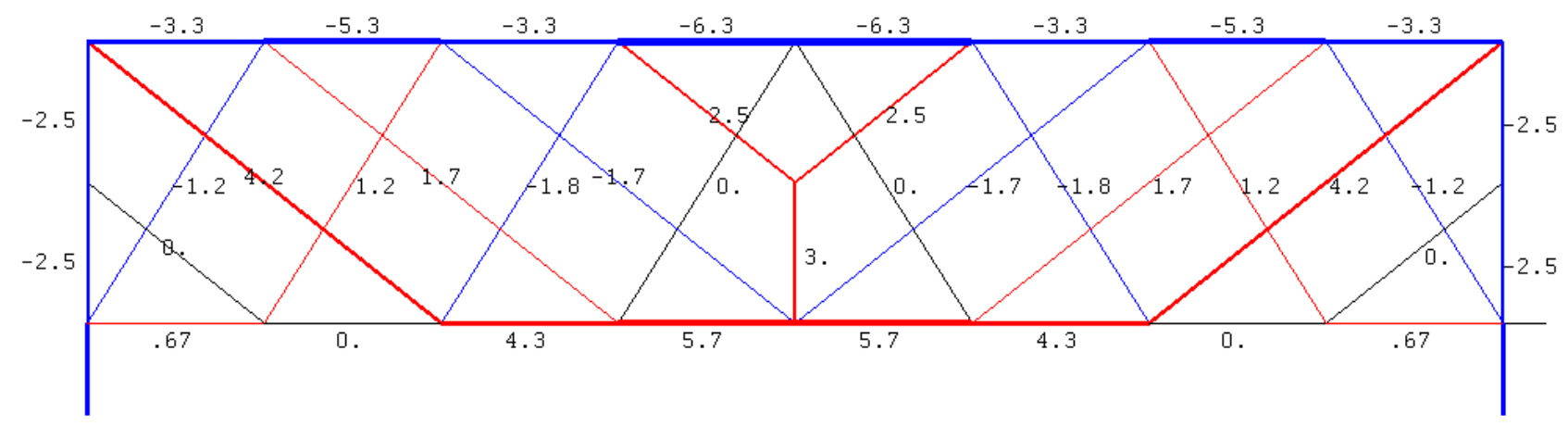

Figure 5. Distribution of relative forces, $n=4$.

\section{CONCLUSION}

The two main results of the study: the functional dependence of the deflection of the truss on the number of panels and the detection of a case of kinematic degeneration of the system. Both the first and the second result owe their appearance to the system of symbolic mathematics. It has been verified that, in numerical form, due to rounding errors, the fact that the determinant of the system of equilibrium equations is zero often escapes. If it is thoughtless to transfer the decision obtained for one number of panels to another, then this may lead to unpredictable consequences during the operation of the structure. Of course, replacing the joints with hard welding will soften the defect inherent in the design. However, to increase the rigidity and reliability of structures, as shown by the present study, it is better to avoid similar effects by correctly choosing the characteristics of the designed structure.

\section{REFERENCES}

1. Kirsanov M.N. The Exact Formulas for Calculating Deflection and Forces in the Rods of the 'Molodechno' Truss With an Arbitrary Number of Panels. // Magazine of Civil Engineering, 2016, No. 1, pp. 33-41.

2. Kirsanov M.N., Tinkov D.V. Analytical Calculation of the Deflection of the Lattice Truss. // MATEC Web of Conferences. 2018. Vol. 193., 03015
3. Kirsanov M.N. A Precise Solution of the Task of a Bend in a Lattice Girder with a Random Number of Panels. // Russian Journal of Building Construction and Architecture, 2018, No. 1(37), pp. 92-99.

4. Arutyunyan V.B. Double Induction for Deriving a Formula for Deflecting a Frame Truss With an Arbitrary Number of Panels. // Postulat, 2018, No. 7, pp. 5.

5. Domanov E.V. The Dependence of the Deflection of the Cantilever Truss on the Number of Panels Obtained in the System Maple // Structural Mechanics and Structures, 2018, Vol. 2, No. 17, pp. 80-86.

6. Rakhmatulina A.R., Smirnova A.A. The Dependence of the Deflection of the Arched Truss Loaded on the Upper Belt, on the Number of Panels. // Science Almanac, 2017, No. 2-3(28), pp. 268-271.

7. Voropay R.A. The Dependence of the Deflection Value of an Externally Statically Determinate Truss with a Cross-Shaped Lattice on the Number of Panels. // Postulat, 2018, No. 7, pp. 7.

8. Tinkov D.V., Safonov A.A. Design Optimization of Truss Bridge Structures of Composite Materials. // Journal of Machinery Manufacture and Reliability, 2017, Vol. 46, No. 1, pp. 46-52.

9. Kirsanov M.N. The Deflection of Spatial Coatings with Periodic Structure. // Magazine of Civil Engineering, 2017, No. 08, pp. 58-66.

10. Kirsanov M.N. Analysis of the Buckling of Spatial Truss With Cross Lattice. // 
Magazine of Civil Engineering, 2016, No. 4, pp. 52-58.

11. Kirsanov M.N. Stress State and Deformation of a Rectangular Spatial Rod Cover. // Scientific Herald of the Voronezh State University of Architecture and Civil Engineering. Construction and Architecture, 2016, No. 3(31), pp. 71-79.

12. Tinkov D.V. Comparative Analysis of Analytical Solutions to the Problem of Truss Structure Deflection. // Magazine of Civil Engineering, 2015, Vol. 5, pp. 66-73.

13. Rabinovich I.M. Kurs Stroitel'noj Mekhaniki Sterzhnevyh Sistem. CHast' 1. Staticheski Opredelimye Sistemy [The Course of Structural Mechanics of Rod Systems. Part 1. Statically Determinable Systems]. Moscow, Leningrad, Stroyizdat, 1950, 388 pages.

14. Myuller-Breslau G. Graficheskaya Statika Sooruzhenij [Graphic Statics of Structures. Volume 1]. Tom 1. Saint-Petersburg, K.L. Rikker, 1908, 505 pages.

15. Kirsanov M.N. Formuly Dlya Rascheta Progiba i Usilij v Shprengel'noj Ferme s Proizvol'nym Chislom Panelej [Formulas for Computing of Deflection and Forces in the Truss with Arbitrary Number of Panels]. // International Journal for Computational Civil and Structural Engineering, 2018, Vol. 14, Issue 2, pp. 9095.

\section{СПИСОК ЛИТЕРАТУРЫ}

1. Kirsanov M.N. The Exact Formulas for Calculating Deflection and Forces in the Rods of the 'Molodechno' Truss With an Arbitrary Number of Panels. // Magazine of Civil Engineering, 2016, No. 1, pp. 33-41.

2. Kirsanov M.N., Tinkov D.V. Analytical Calculation of the Deflection of the Lattice Truss. // MATEC Web of Conferences. 2018. Vol. 193., 03015

3. Kirsanov M.N. A Precise Solution of the Task of a Bend in a Lattice Girder with a
Random Number of Panels. // Russian Journal of Building Construction and Architecture, 2018, No. 1(37), pp. 92-99.

4. Arutyunyan V.B. Double Induction for Deriving a Formula for Deflecting a Frame Truss With an Arbitrary Number of Panels. // Postulat, 2018, No. 7, pp. 5.

5. Domanov E.V. The Dependence of the Deflection of the Cantilever Truss on the Number of Panels Obtained in the System Maple // Structural Mechanics and Structures, 2018, Vol. 2, No. 17, pp. 80-86.

6. Rakhmatulina A.R., Smirnova A.A. The Dependence of the Deflection of the Arched Truss Loaded on the Upper Belt, on the Number of Panels. // Science Almanac, 2017, No. 2-3(28), pp. 268-271.

7. Voropay R.A. The Dependence of the Deflection Value of an Externally Statically Determinate Truss with a Cross-Shaped Lattice on the Number of Panels. // Postulat, 2018, No. 7, pp. 7.

8. Tinkov D.V., Safonov A.A. Design Optimization of Truss Bridge Structures of Composite Materials. // Journal of Machinery Manufacture and Reliability, 2017, Vol. 46, No. 1, pp. 46-52.

9. Kirsanov M.N. The Deflection of Spatial Coatings with Periodic Structure. // Magazine of Civil Engineering, 2017, No. 08, pp. 58-66.

10. Kirsanov M.N. Analysis of the Buckling of Spatial Truss With Cross Lattice. // Magazine of Civil Engineering, 2016, No. 4, pp. 52-58.

11. Kirsanov M.N. Stress State and Deformation of a Rectangular Spatial Rod Cover. // Scientific Herald of the Voronezh State University of Architecture and Civil Engineering. Construction and Architecture, 2016, No. 3(31), pp. 71-79.

12. Tinkov D.V. Comparative Analysis of Analytical Solutions to the Problem of Truss Structure Deflection. // Magazine of Civil Engineering, 2015, Vol. 5, pp. 66-73.

13. Рабинович И.М. Курс строительной механики стержневых систем. Часть 1. 
Статически определимые системы. - М.Л.: Стройиздат, 1950. - 388 с.

14. Мюллер-Бреслау статика сооружений. Том 1. - СПб.: К.Л. Риккер, 1908. - 505 с.

15. Кирсанов М.Н. Формулы для расчета прогиба и усилий в шпренгельной ферме с произвольным числом панелей. // International Journal for Computational Civil and Structural Engineering, 2018, Vol. 14, Issue 2, pp. 90-95.

Mikhail N. Kirsanov, Professor, Doctor of PhysicoMathematical Sciences, National Research University "MPEI", Department of Robotics, Mechatronics, Dynamics and Strength of Machines; 14, Krasnokazarmennaya str., Moscow, 111250, Russia; phone +7(495)362-73-14, e-mail: c216@ya.ru.

Кирсанов Михаил Николаевич, профессор, доктор физико-математических наук, Национальный исследовательский университет "МЭИ", кафедра робототехники, мехатроники, динамики и прочности машин; 111250, Россия, г. Москва, ул. Красноказарменная, дом 14; тел. +7(495)362-73-14, E-mail: c216@ya.ru. 